\title{
General and specific factors in the explanation of regional variation of hospital admission rates: policy consequences for Belgium and the Netherlands
}

\section{J. van der Zee and P.P. Groenewegen}

The Netherlands Institute for Primary Health Care (NIVEL), Utrecht, The Netherlands

Accepted 28 December 1987

\section{Summary}

The analysis of regional variations in hospital admission rates for Belgium and the Netherlands shows that the available number of hospital beds together with the health status of the population (roughly indicated by age-adjusted mortality rates) are common factors to influence these admissions in spite of the fundamental differences between the health care systems of both countries. Further analysis shows that in Belgium the relative number of providers of ambulatory care (general practitioners, internists, paediatricians and gynaecologists) influences the residual admission coefficients negatively. Policy consequences of these findings are discussed. The recent adaptation of the Belgian Hospital Act that enables closure of existing hospitals for planning reasons is hailed with satisfaction. The importance of Roemer's Law - 'a bed built is a bed filled' - is illustrated once again by this analysis.

International comparison of health care systems; Regional variation; Hospital admission rates

\section{Introduction}

Belgium and the Netherlands have much in common: a border, their size, geographical position and economic structure - but not their health care system.

Address for correspondence: Dr. J. van der Zee, Scientific Director, The Netherlands Institute for Primary Health Care (NIVEL), P.O. Box 1568, 3500 BN Utrecht, The Netherlands. 
This mainly is due to historical reasons. The origins of the Belgian health care are to be found in France, while major parts of the Dutch system stem from the German occupation [1-3].

In spite of many differences, both health care systems have common aspects. Both countries have the same sort of health provisions, although conditions that govern them vary.

In a period when rising costs in each health care system force policy makers to reconsider the basic principles of their respective health care systems, interest increases in the greenness of the neighbour's grass [4]. This paper tries to compare the health care systems of Belgium and the Netherlands and to isolate common (or general) and specific factors that influence one major indicator of a health care system: the hospital admission rate. The method chosen is the analysis of regional variation which allows for the separation of factors varying between and within both countries [5]. In our opinion the common factors in the analysis are of major interest for health care policy because experiences of these variables are directly interchangeable.

The structure of this paper is as follows: in part 2 we describe the differences between the Dutch and Belgium health care systems in more detail to provide guidelines for the analysis of regional variation of the hospital admission rates that will be described in part 3 . The possible policy consequences to be derived from these results form a concluding section.

\section{Health care in Belgium and the Netherlands}

In order to describe a health (care) system one needs an analytic framework that remains, however, implicit in most cases [6-8]. Another way of overcoming the wealth of trivial details is a limitation to certain aspects of a health care system. Roemer [9] describes the supply side, Blanpain et al. the role of the state [10] and Deliège et al, the remuneration of health care providers [11].

The implicit analytic framework usually contains some description of the legal and financial conditions that govern a health care system, mostly a thorough and detailed description of the supply of health care providers and sometimes information about the need for health care: the health status of the population. This type of framework was chosen explicitly by the Canadian health economist Robert Evans [12] in his paper about the structure of the health care sector. One of Evans' major theses is, that the use of health services is not equal (neither empirically nor conceptually) to the need for health care, neither is it true that 'supply' is the sole creator of 'demand'. According to Evans the use of health services is a function of supply and need factors under the legal and financial conditions of a health care system.

Evans discerns five 'actors' as he calls them:

- consumers/population

- first line providers 
- second line providers

- insurers

- the state

The relations between these actors form the blueprint of a specific health care system. In our description of the Belgian and the Dutch health care systems we follow this framework.

\section{The demand side - health status of the population}

According to practically all health indicators (smoking perhaps excepted), the Dutch are healthier than the Belgians $[13,14]$. Age-standardized death rates, infant mortality rates, traffic accidents, alcohol consumption are all lower in the Netherlands. The demographic distribution of both countries differs considerably as the Dutch continued to have an elevated birth rate until far into the $1960 \mathrm{~s}$, while the Belgians followed the demographic pattern of France and Germany with a sharp decline after the First World War. This resulted in a higher proportion of the elderly in Belgium (14.1\% over 65 in 1983 for Belgium vs $11.8 \%$ for the Netherlands).

A poorer health status and a larger proportion of old age pensioners are typical for the Belgian situation, compared to the Netherlands.

\section{The supply side}

Groenewegen and Leroy [15] have demonstrated that the number of health care providers in Belgium generally is (much) higher than in the Netherlands. Their findings are being shown in Table 1 . These differences are mainly due to restrictions on the influx of health care professionals in the Netherlands (a numerus clausus for training and an establishment policy for several professions) and a complete freedom of education and establishment in Belgium.

In institutional care things are different. The number of short-term medical and surgical hospital beds does not differ so much between the countries; the number of long-terms beds, however, does so considerably. Evans' distinction in directly

Table 1

Health care provisions per 1000 pop. in Belgium and the Netherlands (1980)

\begin{tabular}{llll} 
& Belgium & The Netherlands & Index $(\mathrm{NL}=100)$ \\
\hline general practitioners & 0.78 & 0.37 & 211 \\
medical specialists & 0.87 & 0.63 & 138 \\
pharmacists (including dispensing & & & \\
$\quad$ general practitioners) & 0.76 & 0.18 & 422 \\
dentists & 0.40 & 0.38 & 105 \\
short term hospital beds & 5.43 & 5.01 & 108 \\
long term hospital beds & 1.28 & 3.32 & 38 \\
\hline
\end{tabular}

Source: Groenewegen and Leroy [15]. 
accessible first line providers and second line providers, whose access is directed via first line providers, is also of use in describing the differences between the Dutch and Belgian health care systems.

In Belgium practically all providers are directly accessible; there are a few exceptions (the district nurse and the physiotherapist, for instance, whose services should be prescribed by a doctor), but even the services of a radiologist or an anaesthesist are accessible without referral.

In the Netherlands there is a hierarchical structure of entry to medical services. General practitioner and district nurse are freely accessible - but access to all specialized medical services is by referral from the general practitioner. Specialists such as the internist, paediatrician or gynaecologist provide a certain amount of primary medical care in Belgium, but only secondary care in the Netherlands.

\section{Financial and legal conditions}

Heesters and Kesenne [16,17] give a synopsis of the sources of finance for the Dutch and Belgian health care systems and a rough distribution of health care expenditure (data for 1982).

The costs of administrating the Belgian system seem to be higher; the Dutch spend their money mainly on institutional care (in the Netherlands practically all medical specialists exert their practice in a hospital-setting), while in Belgium more resources are devoted to independently established private practitioners. In total this amounts to $8.26 \%$ of GNP, spent in 1982 on health care for the Dutch versus $7.53 \%$ for the Belgians

In addition to distribution and extent of health costs there are differences in the way people are insured against costs of health care and how payments for health care are made.

Here major differences exist between the countries. In Belgium there is an almost universal compulsory public insurance coverage (with exception of the selfemployed, whose major risks only are covered) and a complete fee for service payment system with cost-sharing by the insured. The cost-sharing is lower or absent for the so-called WODOs (widows, orphans, disabled and old age pensioners, who receive an income below a certain ceiling).

In the Netherlands there is only a compulsory public health insurance for about $70 \%$ of the population (wage-earners and non-wage-earners with an income below a certain ceiling); the rest of the population is covered by private and voluntary health insurance. After the abolishment of the voluntary public insurance in April 1986 this proportion dropped to $62 \%$. The maximum 'risk' for the insurers is one year of hospital stay. All costs after the 366th day in an institution for all inhabitants of the Netherlands are covered by the General Exceptional Medical Expenses Act, for which only employers pay the premiums.

The remuneration of health care providers is different too; there is a complete fee-for-service system in Belgium. In Holland general practitioners receive a capitation fee for their publicly insured patients and send bills to their private patients [18]; medical specialists and most other providers are being paid on a fee-for-serv- 
ice base. The publicly insured receive their health services in kind without copayment (prescriptions excepted).

The privately insured usually receive either partial or full reimbursement from their insurance companies. This depends on the kind of policy. There is an enormous variation: coverage for general practitioner's services may be in- or excluded, and there may be no, low or high copayment rates for the insured.

\section{Consequences of differences: guidelines for the analysis}

From this description of the Belgian and Dutch health care systems the following guidelines for analysis can be derived.

The higher proportion of the elderly and the poorer health status of the population in Belgium may yield higher hospital admission rates there. The same goes for the somewhat higher number of hospital beds in Belgium. Other factors, however, might counterbalance these results. For instance, the fact that medical specialists in Belgium commonly exert their profession in an ambulatory setting, while in the Netherlands they usually are attached to hospitals and receive part of their earnings from remuneration per patient-day [19].

The incentive to keep patients out of the hospital is stronger in Belgium than in the Netherlands: the capitation-fee-system for general practitioners in the Netherlands cncourages referrals to medical specialists, and spccialists profit from admission. So we predict a weaker correlation between the supply of hospital beds and the admission rate in Belgium than in the Netherlands.

The copayment system for patients in Belgium might act as a threshold for medical consumption - excepting the WODOs (Widows, Orphans, Disabled and Oldage pensioners), who are generally being excluded from copayment. The Dutch 'private patients' who do not receive services in kind (like their publicly insured counterparts) but who have to pay bills, might also be inhibited in their consumptions of medical services.

The results of studies that tried to sort out the contamination between type of insurance and health status are ambiguous, however. For the Netherlands Van Vliet and Van de Ven $[20,21]$ state that the major difference is not between public and private insurance. Coverage for the services of the general practitioner (standard for public health insurance and optional for private insurance) is the major determinant of the use of services in general. They cannot, however, discern whether it is the behaviour of providers or consumers that cause the differences found. Administrative requirements that differ greatly between the private and public insurance may add to the confusion too. Nevertheless consumption is higher for the publicly insured, so empirically and pragmatically an indicator like the proportion of publicly insured could be part of our model.

In fact the same goes for Belgium. There is a similar dispute about the influence of full reimbursement for the WODOs (the non-actives). The results of a recent study by Vuylsteek et al. [22] showed results comparable to those of Van Vliet and Van de Ven.

Implicitly we described three types of variables. 
The first type is present in both health care systems and is expected to exert the same sort of influence in both countries (health status of the population, number of hospital beds). These variables may be called 'general'.

The second type is present in both systems, but due to different conditions, is

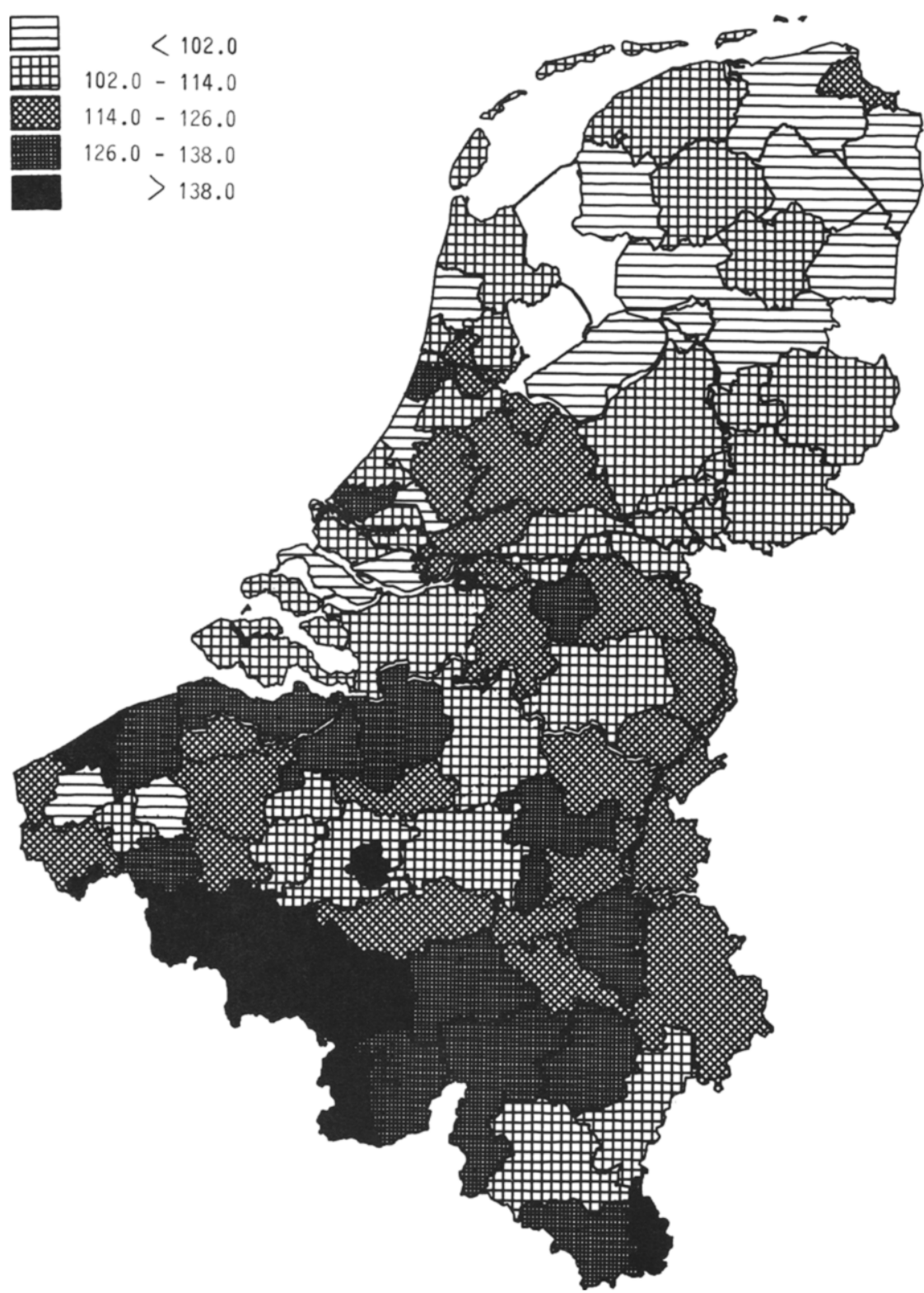

Fig. 1 Geographical distribution of the hospital admissions per 1000 inhabitants in Belgium and the Netherlands (1979). 
expected to exert a different influence. The number of health care providers (because of the different accessibility of medical specialists) is an example of this type.

The third type at last is present in one of both systems only. The proportion of 'non-actives' in Belgium - (the WODOs) - the proportion of privately insured patients in the Netherlands or the ownership of hospitals by public health insurance funds in Belgium.

The latter two types of variables can be called 'specific'. The existence of these specific variables creates some analytic problems, but we will come to that later.

\section{Regional variations of hospital admission rates}

In the foregoing section we divided the factors that may influence hospital admission rates into 'general factors' that are supposed to exert this influence both in Belgium and in the Netherlands (and in other health care systems, too), and variables specific for each respective country. This also determines our method of analysis - a regression analysis in two stages, where the specific variables influence the residuals that remain after the influence of the general variables has been taken into account. We will describe the general model first and then the specific model.

\subsection{A general model for the explanation of hospital admission rates}

We consider all factors that represent the need for health care (mainly the health of the population but also factors that represent a general inclination to seek care) as general factors.

The number of hospital beds refers to Roemer's Law (a bed built is a bed filled), which is the reason we include it in the general model. Finally we included the average length of stay per admission in the general part of the model, but we will explain this later.

The dependent variable is the number of admissions in general hospitals per 1000 inhabitants [23]. Fig. 1 shows the distribution over both countries. The national averages in 1974 and 1979 were 118 versus 104 and 128 versus 110 for Belgium and the Netherlands, respectively.

The lowest rates are being found in the Northern provinces of the Netherlands: the highest rates in the Walloon mining district (the province of Hainaut) in Belgium

The independent variables have been derived from the foregoing section and can be divided into demand-factors, supply-factors and conditional factors.

\section{Demand-factors}

Direct measures of the health status of the population are not available at this level of aggregation. Beside this, most indicators are not independent of the use of health care facilities. We had to choose 'proxies' for the health status. The age- 
distribution of the population is a well-known proxy (in this case the proportion of inhabitants over 65 years of age). Another proxy is the age-standardized mortality rate. It is a rough indicator but a stable and a reliable one, because no validity problems about the cause of death can interfere. Between countries that have

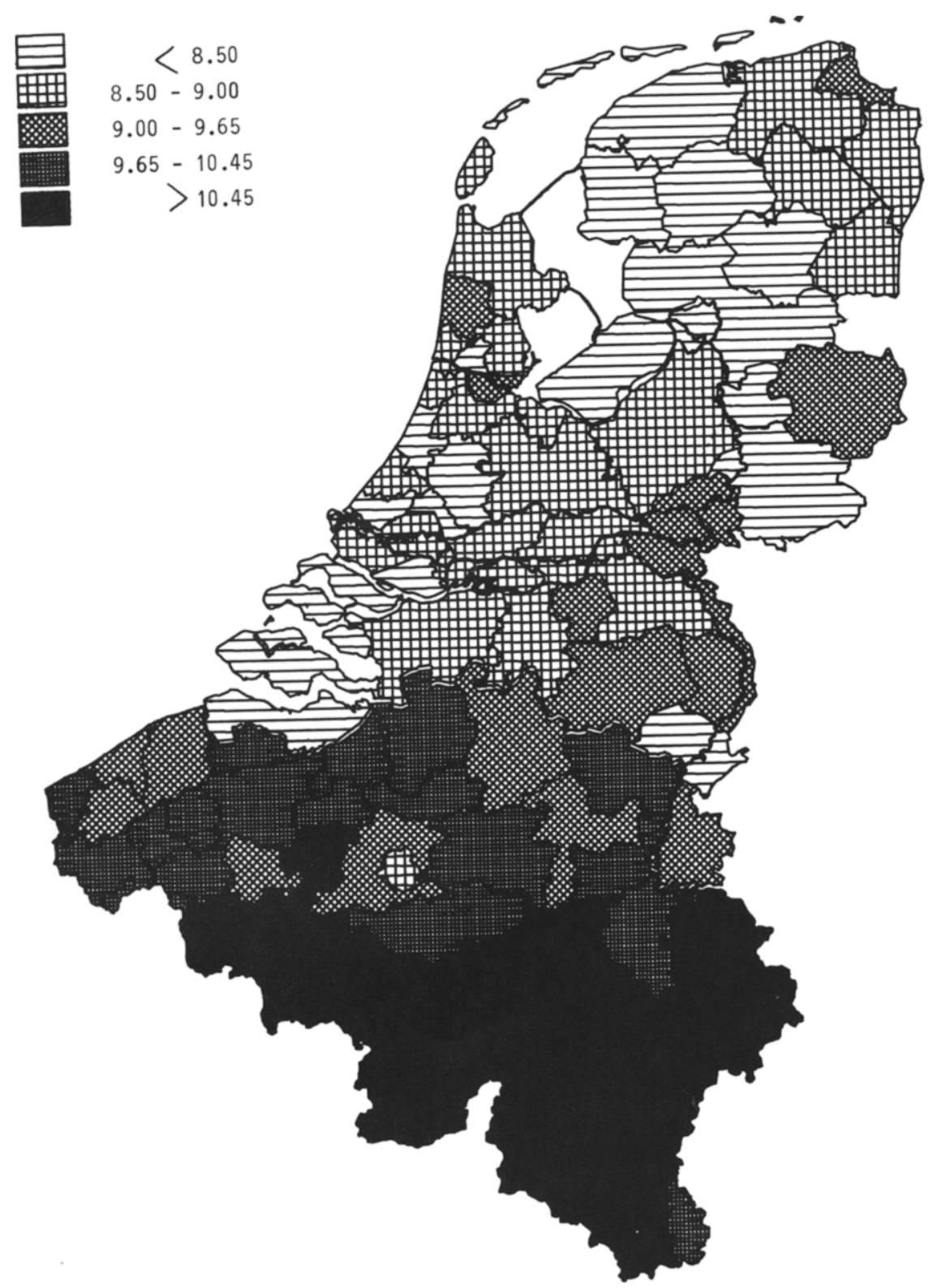

Fig. 2 Geographical distribution of age-standardized death rates in Belgium and the Netherlands (1979) (number of deaths per 1000 population). 
a comparable mortality pattern (top three causes of death - cardiovascular diseases, neoplasms and accidents), the age-standardized death rate gives a crude but valid overall impression of the relative health status of the population. The use of the overall (standardized) death rates for comparative purposes has been criticized by several authors [24-27]. The criticism, however, questioned the use of stand-

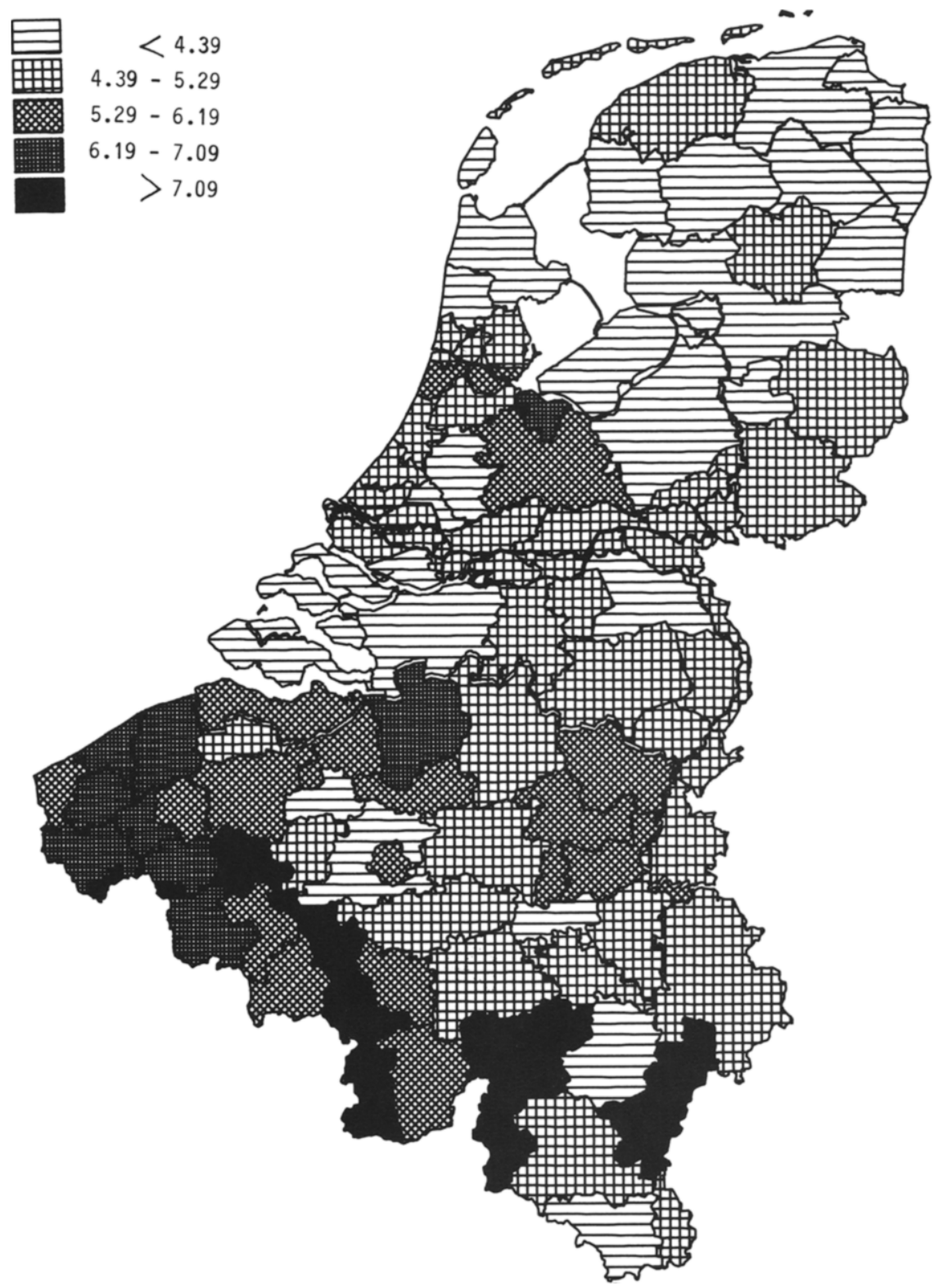

Fig. 3 Geographical distribution of available hospital beds per 1000 pop. in Belgium and the Netherlands (1979). 
ardized death rates to evaluate the efficiency of a certain health care system. A more specific analysis, limited to rates of 'avoidable death' is more appropriate for this purpose.

In this study death rates are not being used as 'outcome criteria' but rather as input factors that might explain variation in the use of health services.

We find the arguments defending the use of standardized death rates for the allocation of resources in the British National Health Service $[28,29]$ more convincing than most of the criticisms [30,31], particularly since our use of this indicator is much more limited.

As Mackenbach and Koch state [32]: the core of the criticism concerning the use of mortality rates for the planning of health services is the ambiguous relation between mortality and morbidity. Morbidity figures, however, are nearly always contaminated with the use of health services. Though standardized mortality rates are suboptimal indicators, the alternatives are even worse.

Fig. 2 shows the regional distribution of the age-standardized death rates.

In the Netherlands the coastal parts seem to have the lowest death rates. In Belgium there is a clear distinction between the French speaking and Dutch speaking parts of the country. The poorer health status of the Belgian population is clearly visible on the map.

\section{Other demand factors}

We also included two other 'proxies' of the demand for health care. The average income of the population and the degree of urbanization of the region.

Income (or rather socio-economic position) is universally considered as having a direct relationship with health [33-37] while the propensity to seek medical care is known to be lower in rural areas [38]. For the degree of urbanization the number of inhabitants per $\mathrm{km}^{2}$ was taken as an indicator. The income of the population was (due to monetary complications) transferred to standard (z-)scores.

\section{Other variables in the general model}

The number of hospital beds per 1000 population. The technicalities of the computation of this variable [39] are not relevant to this paper. The geographical distribution of it is shown in Fig. 3.

The inclusion of the average length of stay per admission as a variable in the general model needs more explanation because of our focus on the explanation of hospital admission-rates. Usually the average length of stay is the next dependent variable in a series of consecutive or simultaneous equations $[40,41]$ and theoretically this is more adequate - but there is always an artificial reciprocal relationship between the two. The longer the average length of stay per admission the less admissions are possible and vice versa. As long as one refrains from strict causality, the inclusion of this variable is defendable. 
Table 2

Summary table of the results of a general model for regional variations in hospital admission rates for the Netherlands and Belgium (data from 1979)

Weighted least-squares regression analysis. (B-coefficients and T-values between brackets.)

\begin{tabular}{|c|c|c|c|c|}
\hline & \multicolumn{2}{|l|}{1979} & \multicolumn{2}{|l|}{1974} \\
\hline & Belgium & 'The Netherlands & Belgium & The Netheriands \\
\hline age adjusted death rates $0 / 00$ & $\begin{array}{l}14.740 \\
(3.76)\end{array}$ & $\begin{array}{l}1.552 \\
(0.40)\end{array}$ & + & + \\
\hline pop. of over 65 & $\begin{array}{c}-1.374 \\
(-1.14)\end{array}$ & $\begin{array}{c}-0.622 \\
(-0.54)\end{array}$ & & \\
\hline income of pop. (z-scores) & $\begin{array}{c}-2.95 \\
(-0.11)\end{array}$ & $\begin{array}{l}-0.120 \\
(-0.10)\end{array}$ & - & \\
\hline pop. density $\times 10^{-2}$ & $\begin{array}{l}-0.830 \\
(-4.25)\end{array}$ & $\begin{array}{l}-0.218 \\
(-1.07)\end{array}$ & - & \\
\hline hospital beds per $0 / 00$ & $\begin{array}{r}6.812 \\
(3.50)\end{array}$ & $\begin{array}{r}8.824 \\
(3.02)\end{array}$ & + & + \\
\hline length of stay per admission & $\begin{array}{c}0.32 \\
(0.10)\end{array}$ & $\begin{array}{r}-1.546 \\
(0.81)\end{array}$ & & - \\
\hline $\begin{array}{l}\text { variance explained } \\
\text { no. of regions } 85 \text { (Belgium } 43 \text {, }\end{array}$ & $\begin{array}{l}0.53 \\
\text { Netherla }\end{array}$ & 0.42 & 0.32 & 0.44 \\
\hline
\end{tabular}

\section{Results of the general model}

We will summarize the results of the analysis for the general part of the model first. In Table 2 B-coefficients and T-values are to be found. Data for 1979 are presented but results for 1974 have been indicated roughly (with + or - indicating significant coefficients).

The method used is the generalized least-square regression analysis, that takes into account the population size of the region. This is an alteration of the original report, where ordinary least-squares regression analysis was used. Although the results of this method differ only marginally, the methodologically more appropriate method of weighted least-squares regression is being used in this article

The only variable that shows an undeniable influence is the number of available hospital beds. The age-adjusted death rates do relate to the hospital admission rates, but not in all four cases. For the Netherlands, in 1979, the relation is absent. Some variables show their influence in Belgium only (the population density, for instance in 1979 and 1974) while the income of the population was related negatively with the admission rates in 1974 in Belgium.

In 1974 and in the Netherlands only, the expected reciprocal relationship of admission rates and the average length of stay per admission has been found.

We decided to include the age-adjusted death rates and the number of available hospital beds in the general model and to calculate residual variation after the influence of both variables has been eliminated. These residual admission rates form 
the object of our analysis of the second step of the study, where the influence of specific system-related variables was to be found.

\subsection{The specific model}

There are two types of specific variables: one type is present in both countries but is supposed to exert a different influence in each country; the other type is present in one of the countries only (unique factors).

To begin with the latter type:

- In the Netherlands the proportion of publicly insured patients per region is a unique variable. The overall hospital admission rate in this group is higher, partly due to the form of insurance $[20,21,42]$.

- In Belgium the same goes for the proportion of WODOs (non-actives) - but, here too, the impact of the insurance factor has been blurred by the health status of the population [22].

For Belgium we also included the proportion of non-wage earners, who, in the Belgian insurance system, have insurance coverage for hospital costs only. Their loss of income usually is covered marginally too - so one could expect a negative relationship with admission rates. Finally the ownership of hospitals is a specific variable. Unlike those in the Netherlands, health insurance funds are integrated forwards into the hospital sector in Bclgium, they are allowed to own hospitals and give discounts to their insured. We expect a cost reduction and probably admission reduction effect of this, analogous to the results found for Health Maintenance Organizations in the U.S.A. [43,44].

The second group of specific factors can be found in each system, but due to considerable differences between the systems, the expected effects differ greatly.

These variables are:

- the birth rate (almost 100\% clinical deliveries in Belgium; while in the Netherlands the division between clinical, out-patient and home deliveries was 45, 20 and $35 \%$ in 1979). So we expect a positive relation with admission rates in Belgium and no relation in the Netherlands (inversely related to the proportion of elderly).

- the density of general practitioners - in the Netherlands no relation with hospital admissions is being predicted. For Belgium we have no expectations $[38,40,45]$.

- the density of internists, gynaecologists and pediatricians. In Belgium these are directly accessible, in the Netherlands they are not. They provide general medical care, mostly for the younger, better educated and urbanized part of the population $[46,47]$. This might reduce admission rates in Belgium, certainly when combined with g.p. density. We expect a strong ambulatory care to form a counterbalance for hospital care. The form of this counterbalance may be a lower coefficient for hospital beds in Belgium and a negative relationship between the admission rate and the relative number of ambulatory care providers. 
- the density of 'other' specialists. In the Netherlands we expect the density of specialists to influence admission rates positively $[41,48]$.

\section{Results}

The results of the second stage of this analysis are disappointing; it is not even worth presenting them in a table; they can be summarized easily.

- In the Netherlands none of the specific variables had any significant influence on the residual admission rates. Partly this had been predicted, but the lack of relationship between the number of (hospital-based) medical specialists and the residual admission rates is somewhat puzzling, and contradictory to the results of Wijkel [48].

- In Belgium the expected positive correlation was found between the birth rate and the residual admission coefficient, while the relative number of primary care physicians (general practitioners, internists, paediatricians and gynaecologists) compared to the number of 'other' (usually hospital-based) specialists did influence the residual admission rates negatively. The number of 'non-actives' in Belgium showed no relation with the residual admission coefficients after the influence of the health status of the population had been eliminated in the first stage. This corroborates the above-mentioned results of Vuylsteek and others $[22]$.

\section{Discussion: the general character of Roemer's Law}

The results of our analysis show one genuine general variable: the number of hospital beds available for the population. Both in 1979 and in 1974 the number of beds influenced the number of hospital admissions in the Netherlands and in Belgium. The health status of the population (as indicated by the age-adjusted death rate) has only in three of the four cases (the Netherlands in 1979 excepted) a significant influence. The influence of other variables was negligible; no additional influence of the insurance variables (like the proportion of publicly insured patients in the Netherlands and the proportion of 'non-actives' in Belgium) could be found after accounting for the health status of the population. The weaker coefficient for hospital beds in Belgium might be the result of a stronger emphasis on ambulatory general and specialistic medical care.

So Roemer's Law can be applied in Belgium and the Netherlands. A bed built attracts patients, although the 'filling' of the bed, as appears from the gradually decreasing occupation rates, is not a completely adequate description of what is going on. Nevertheless, our results support the idea of a strengthened bed reduction policy in both countries. As Nys [49] pointed out in his thorough study of supply-controlling instruments in France, Belgium and the Netherlands, there is such a policy in the latter two countries. The Hospital Facilities Act in the Netherlands and the Hospital Act in Belgium have been designed to reduce the uncontrollable 
growth of hospital facilities. Until very recently, however, one fundamental difference existed between the legislation in both countries. With the Belgian legislation the closure of an existing hospital was (until 1986) practically impossible, while the Dutch Hospital Facilities Act (and its successor the Health Care Provision Act) provide legal means for this. Dewalsche and Groot [50] emphasize the inadequacy of the Belgian legislation, because in 1984, the number of hospital beds was still growing. In the Netherlands the reduction of the number of hospital beds is proceeding slowly despite strong local protest. The closure of an existing hospital is so exhausting that the Dutch Secretary of State for Public Health complained that his general budgetting measures were much easier to proclaim and with faster and better results [51].

The creation of a considerable number of long-term hospital beds in the Netherlands (with the purpose of emptying expensive acute beds) did not solve the problem. The reason for this is - that is true indeed - that half of the number of admissions to long-term hospitals comes from short-term hospitals, but this half does not even form $1 \%$ of the total number of hospital discharges. Since, in 1978, the criteria for admission in homes for the aged became much stricter, the population of long-term hospitals and homes for the aged began to converge. There still are major differences, but not enough (as Remmen [52] concluded after a comparative study) to justify a completely separated organizational and financial framework.

Now, there exist two completely different types of provision of comparable care: the (medical) nursing homes, funded directly out of the social security system (the Exceptional Medical Expenses Act) and the (social) homes for the aged (with sickroom facilities) funded out of general means through the budget of the Ministry of Welfare, Public Health and Culture. This example should certainly not be copied in Belgium. For policy reasons the nursing homes and the homes for the aged should not be separated to avoid complicated luning problems. A policy of hospital bed reduction is still advisable for Belgium and the Netherlands. Now that Belgium too possesses the legislation for closing hospitals or hospital-departments based on reasons other than danger for the public health, the growth may be reduced. The closure of a hospital, however, will arouse vehement local protest and exhausting quiet lobbying, that is hard for politicians to resist. May the results of this study support them.

\section{Acknowledgements}

This article is partly a synopsis and partly an extension (in the direction of health care policy) of a publication titled 'Hospital admissions in the Dutch and Belgian health care systems: an analysis of regional variation' [19]. Readers interested in methodological and technical details can apply for a copy of it. We thank our colleague Jan Kerssens for the replication of the analysis applying the 'generalized least-squares regression approach'. Part of the original Belgian data stems from Xavier Leroy [53-55] to whom we are grateful for his thorough scientific work. 


\section{References}

1 Schepers, R., De opkomst van het Belgisch medisch beroep. Dissertation, Katholieke Universiteit Leuven, 1983.

2 Huysmans, F., Juffermans, P., Lagro, B., van Niekerk, B., Smits, F. and Vlaar, H. (Eds.), Gezondheidszorg in Nederland, Socialistische Uitgeverij Nijmegen, Nijmegen, 1983.

3 Roscam Abbing, H.D.C. and Rutten, F.F.H., Verleden en toekomst van het ziektekostenverzekeringsstelsel in Nederland, Kluwer, Deventer, 1985.

4 Peeters, R.F., Stevens, F.C.J. and van der Zee, J. (Eds.), Het gras aan gene zijde. Vergelijking van het Nederlandse en Belgische stelsel van gezondheidszorg en sociale zekerheid op het gebied van zickte en invaliditeit, special issue of, Gezondheid \& Samenleving, 6 (1985) 217-339.

5 Groenewegen, P.P. and van der Zee, J., The comparison of health care systems through regional analysis: the case of hospital admissions in Belgium and the Netherlands - paper for the AAG-IBG conference at Rutgers University, New Brunswick, 1986.

6 Foets, M. and Nuyens, Y., Focus op de Belgische gezondheidszorg, Leuven, Sociologisch Onderzoeksinstituut de Katholieke Universiteit, 1980.

7 Raffel, M.W. (Ed.), Comparative Health Systems: Descriptive Analysis of Fourteen National Health Systems, Pennsylvania State University Press, 1984.

8 Deppe, H.U. (Ed.), Gesundheitssysteme und Gesundheitspolitik in Westeuropa, Campus Verlag, Frankfurt, 1983.

9 Roemer, M.I. and Roemer, R.J., Health care systems and comparative manpower policies, Marcel Dekker, New York and Basel, 1981.

10 Blanpain, J., Delesie, L. and Nys, H., National Health Insurance and Health Resources, Harvard University Press, Cambridge, 1978.

11 Deliège, D., Lievens, J. and Zecgers-Doorcman, Ch., Medical doctors in the ninc countries of the common market, systems of payment and levels of remuneration, Université Catholique de Louvain, Brussels, 1975.

12 Evans, R.G., Incomplete vertical integration: the distinctive structure of the health care industry. In van der Gaag, J. and Perlman, M. (Eds.), Health, Economics and Health Economics, Elsevier, Amsterdam, 1981

13 Casselman, J. and Knibbe, R.A., Alcoholgebruik en alcoholproblemen in België en Nederland, Gezondheid \& Samenleving, 6 (1985) 256-264.

14 Foets, M. and van der Zee, J., Gezondheidstoestand en behoefte aan gezondheidszorg. In R.F. Peeters, F.C.J. Stevens and J. van der Zee (Eds.), Basisgegevens van de Belgische en Nederlandse systemen van de gezondheidszorg en sociale zekerheid bij ziekte en invaliditeit, Van Loghum Slaterus, Deventer, 1985.

15 Groenewegen, P.P. and Leroy, X., De aanbodzijde in de Belgische en Nederlandse gezondheidszorg. In R.F. Peeters, F.C.J. Stevens and J. van der Zee (Eds.), Basisgegevens van de Belgische cn Nederlandse systemen van gezondheidszorg en sociale zckerheid bij zickte cn invaliditcit, Van Loghum Slaterus, Deventer, 1985.

16 Heesters, J.P. and Kesenne, J., De financiering van de Nederlandse en Belgische gezondheidszorg In R.F. Peeters, F.C.J. Stevens and J. van der Zee (Eds.), Basisgegevens van de Belgische en Nederlandse gezondheidszorg en sociale zekerheid bij ziekte en invaliditeit, Van Loghum Slaterus, Deventer, 1985.

17 Heesters, J.P. and Kesenne, J., Financiering en kosten van de gezondheidszorg in Nederland en België - een globale analyse van de gevonden verschillen, Gezondheid \& Samenleving, 6 (1985) 311-320.

18 The Dutch association of general practitioners is unlike the usual connotation with the term 'private patient' not in favour of increasing their numbers. On the contrary, it pleaded to abolish 'private patients' and to transfer them all to the public insurance with its satisfying capitation fee.

19 Groenewegen, P.P. and van der Zee, J., Hospital admissions in the Dutch and Belgian health care systems: an analysis of regional variation, Utrecht, Netherlands institute of primary health care (NIVEL), 1985, Ch. 4.

20 Ven, W.P.M.M., van de and van Vliet, R.C.J.A., Effects of cost sharing in the health care sector, Gezondheid \& Samenleving, 6 (1985) 238-245. 
21 Vliet, R.C.J.A. van and van de Ven, W.P.M.M., Consumptieverschillen tussen ziekenfonds- en particulier verzekerden nader onderzocht. Overzicht van empirische bevindingen. Gezondheid \& Samenleving, 7 (1986) 81-94.

22 Vuylsteek, K., De Craene, I., De Prins, L., Tasman, C., Leroy, X., Deliège, D. and Gomers, A., Verhoogde tegemoetkoming van de ziekteverzekering en het medisch verbruik van de WIGW, RIZIV, Brussel, 1985.

23 For technical details see: Groenewegen and Van der Zee, (o.c., 1985) Ch. 5, (p. 29-31).

24 Cochrane, A.L., St. Leger, A.S. and Moore, F., Health service 'input' and mortality 'output' in developed countries. Journal of Epidemiology and Community Health, 32 (1978) 200-205.

25 Philipsen, H., Internationale vergelijking van welvaart, gezondheidszorg en levensduur: het probleem van Galton, Gezondheid \& Samenleving, 1 (1980) 5-17.

26 Philipsen, H., Gezondheid en gezondheidszorg in Belgie en Nederland. Gezondheid \& Samenleving, 6 (1985) 223-231.

27 Mackenhach, J.P., Moens, G.F.G. and Lagasse, R., Verschillen tussen Nederland en België in door gezondheidszorg vermijdbare sterfte, Gezondheid \& Samenleving, 6 (1985) 265-277.

28 DHSS, Sharing resources for health in England; report of the Resource Allocation Working Party, HMSO, London, 1976.

29 Bennet, A.E. and Holland, W., Rational planning or muddling through; Resource allocation in the NHS, Lancet, i (1977) 464-466.

30 Forster, D.P., Mortality, morbidity and resource allocation, Lancet, i (1977) 997-998.

31 Palmer, S.R., The use of mortality data in resource allocation. In Brotherston, J. (Ed.), Morbidity and its Relationship to Resource Allocation, Welsh Office, Cardiff, 1978.

32 Mackenbach, J.P. and Koch, W.A., Gebruik van sterftecijfers bij de vaststelling van regionale financiële plafonds, Tijdschrift voor Sociale Geneeskunde, 60 (1982) 490-497.

33 Jong, G.A., de (Red.), Ongelijkheid in gezondheid en gezondheidszorg, special issue, Tijdschrift voor Sociale Geneeskunde, 58 (1980).

34 Luft, H.S., Poverty and health, causes and consequences of health problems, Ballinger, Cambridge, MA, 1978

35 Towsend, P. and Davidson, N., Inequalities in health, Penguin Books, Hammondsworth, 1982.

36 Scrivens, E. and Holland, W.W., Inequalities in health in Britain (a critique of the report of a research working party), Effective Health Care, 1 (1983) 97-107.

37 Zee, J., van der, Sociale klasse en ziekte in de huisartsenpraktijk; een pleidooi voor de empirie. In W.G.W. Boerma en L. Hingstman (Eds.), De Eerstelijn Onderzocht, Van Loghum Slaterus, Deventer, 1985.

38 Zee, J., van der, De vraag naar diensten van de huisarts, Dissertation, Rijksuniversiteit Limburg, Nederlands Huisartsen Instituut, Utrecht, 1982.

39 Groenewegen, P.P. and van der Zee, J., (o.c. 1985) Ch. 6.

40 Posthuma, B.H. and van der Zee, J, , Tussen Eerste en Tweede Echelon, parts 1 and 2, Nederlands Huisartsen Instituut, Utrecht, 1977, 1978.

41 Rutten, F.F.H., The use of health care facilities in the Netherlands, Dissertation, Rijks Universiteit te Leiden, 1978.

42 Mootz, M., The need for health care utilization and its relation to insurance coverage for medical expenses, Gezondheid \& Samenleving, 6 (1985) 232-237.

43 Luft, N.S., Health Maintenance Organizations: dimension of performance, Wiley, New York, 1981.

44 Schut, F.T., Health Maintenance Organizations, Uitgeversmaatschappij De Tijdstroom, Lochem, Gent, 1986.

45 Boots, J.M.J., Verkleining van de huisartsenpraktijk, Gezondheid \& Samenleving, 5 (1984) 11-20.

46 Programmatie van het Wetenschapsbeleid, Eerstelijnsgezondheidszorg, Nationaal onderzoeksprogramma in de sociale wetenschappen, Brussel, 1978, part $1 \mathrm{H}$.

47 Foets, M.M., Ziekte en gezondheidsgedrag. De ontwikkeling van de sociologische theorievorming en van het sociologisch onderzoek. Dissertation, Katholieke Universiteit te Leuven, 1986.

48 Wijkel, D., Samenwerken en verwijzen, Dissertatie Rijks Universiteit te Groningen, NIVEL, Utrecht, 1986.

49 Nys, H., De plan-matige gezondheidszorg, de Tijdstroom, Lochem, 1981. 
50 Dewalsche, R. and Groot, L.M.J., Het Belgische tariefbeleid voor de intramurale gezondheidszorg, in relatie tot kostenbeheersing, Tijdschrift voor Sociale Gezondheidszorg, 63 (1985) 73-78.

51 Reijden, J.P., van der, Speech at the opening of the NIVEL (Netherlands Institute for Primary Health Care), Utrecht, November 7th, 1985.

52 Remmen, J.W.M., Bejaardenoordbewoners of Verpleeghuispatienten? Dissertation, 1985, Katholieke Universiteit Nijmegen.

53 Leroy, $\mathrm{X}$., Offre et consommation de soins en médécine générale, analyse régionale, mécanismes du marché, indicateurs de besoins, Nationaal onderzoeksprogramma in de sociale wetenschappen, Brussel, 1978.

54 Leroy, X., L'accès aux soins médicaux. Analyse régionale de l'offre et de la consommation, Brussel, 1981.

55 Leroy, X., L'accès aux soins médicaux. Tôme IV. Données régionales de l'offre et de la consommation en 1979. Université Catholique de Louvain, 1983. 